\title{
Review Article \\ Traditional Chinese Herbal Medicines for Treating HIV Infections and AIDS
}

\author{
Wen Zou, ${ }^{1}$ Ying Liu, ${ }^{1}$ Jian Wang, ${ }^{1}$ Hongjuan $\mathrm{Li}^{2}{ }^{2}$ and Xing Liao ${ }^{3}$ \\ ${ }^{1}$ Center of AIDS Treatment with Traditional Chinese Medicine, China Academy of Chinese Medical Sciences, \\ 16 Dongzhimennei South Street, Dongcheng District, Beijing 100700, China \\ ${ }^{2}$ Department of Diagnosis with Chinese Medicine, University of Traditional Chinese Medicine, Beijing 100029, China \\ ${ }^{3}$ Institute of Basic Research in Clinical Medicine, China Academy of Chinese Medical Sciences, Beijing 100700, China \\ Correspondence should be addressed to Jian Wang,62tiger@163.com
}

Received 16 July 2012; Revised 1 December 2012; Accepted 7 December 2012

Academic Editor: Ching Liang Hsieh

Copyright ( $\odot 2012$ Wen Zou et al. This is an open access article distributed under the Creative Commons Attribution License, which permits unrestricted use, distribution, and reproduction in any medium, provided the original work is properly cited.

To assess the effects of TCHM on patients with HIV infection and AIDS, we reviewed eleven randomized placebo-controlled trials involving 998 patients. Due to the limited number of RCTs for included trials and the small sample size of each study, we are not able to draw firm conclusions concerning TCHM therapy in treating patients with HIV infection and AIDS. However, some high-quality clinical studies do exist. Studies of diarrhea and oral candidiasis, which are challenging symptoms of AIDS, were demonstrated to have positive effects. Study of peripheral leukocytes, which are a side effect of antiretroviral drugs, suggested that an integrated treatment approach may be of benefit. The overall methodological quality of the trials was adequate; however, randomization methods should be clearly described and fully reported in these trials according to the Consolidated Standards of Reporting Trials (CONSORT).

\section{Introduction}

Although human immunodeficiency virus (HIV) infection was first reported in China in 1985, the magnitude of its spread was not evident until the epidemic among former plasma donors across central China was realized. Poor, rural farmers sold plasma to unscrupulous collectors under unsanitary conditions during the early to mid-1990s, resulting in untold numbers of infections [1]. The Chinese government initiated the China Comprehensive acquired immuno-deficiency syndrome (AIDS) Response program, which is also called China National Free Antiretroviral Treatment Programme (NFATP), to provide free HIV treatment in 127 counties with former plasma donors across central China. This program began as a pilot-treating 100 patients in 2002-but was rapidly scaled up to cover 82,540 patients to the rest of the country by the end of 2009 [2].

To date, an estimated 740,000 people in China are infected with HIV, most of whom are injecting drug users (IDUs), female sex workers, men who have sex with men, former plasma donors, or blood transfusion recipients. As of Dec 31, 2009, 323,252 people were reported as having HIV in China [3]. People living with HIV and AIDS have become a significant health issue in China, and an increasing number of HIV-infected individuals are in need of care.

The availability of highly active antiretroviral therapy (HAART) has markedly improved the survival rate and quality of life in patients infected with HIV, data from the NFATP show virological suppression, increased CD4+ cell counts, and a pronounced decrease in mortality in patients who have received treatment [4]. At present, however, there is still no cure for HIV. The use of antiretroviral drugs has been associated with several toxicities that limit their success. Some acute and chronic toxicities associated with these drugs include hypersensitivity reactions, neurotoxicity, nephropathy, liver damage, and the appearance of body fat redistribution syndrome and the different metabolic alterations that accompany it. The persistence of prolonged HIV reservoirs in patients on effective antiretroviral therapy is the main hurdle to HIV eradication [5]. 
Three types of treatment systems are practiced in Chinese society: (a) HAART offered by health care professionals in clinics and hospitals; (b) Buyao, which is over-thecounter popular medicine and includes teas, soups, tablets, herbal preparations, and tonics, which are similar to herb supplements used in some Western countries; and (c) traditional chinese medicine (TCM), provided by trained Chinese herbalists, which incorporates a wide range of theories, therapies, and practices. Many Chinese people use all three types of treatment simultaneously. Generally, people with HIV infection use TCHM for four main reasons: to enhance their immune function, to treat symptoms, to improve their quality of life $(\mathrm{QoL})$, and to reduce side effects related to medications [6]. Comprehensive TCM intervention started from 2004, National Free TCM HIV/AIDS Treatment Program had been launched by The State Administrative bureau of Traditional Chinese Medicine, and quickly scaled up from 5 provinces (Henan, Hebei, Anhui, Hubei, Guangdong) to 19 provinces, autonomous regions, and municipalities in China, 9267 cases have been treated with TCM accumulatively by 2009, retrospective data analysis suggested promising effect in promoting CD4 + cell [7].

When HAART is the dominant method of treatment, however, its use is complemented by the presence of complementary and alternative medicine (CAM) [8]. The majority of people living with HIV/AIDS are using complementary medicine [9], in China and South Africa these treatments are used as primary treatments [10]. Commonly, CAM includes a wide range of practices that do not fit within the dominant allopathic model of health care [11], including but not limited to herbalism, traditional chinese herbal medicine (TCHM), acupuncture, and diet-based therapies. TCHM has been used in Chinese society for more than 5,000 years. In the TCHM approach, the body is recognized and treated as a whole entity, and diseases are identified as conditions caused by internal imbalances. The role of doctors is to identify imbalances and then correct them; the body is then expected to be able to heal itself [12]. TCHM, among the most widespread of complementary therapeutic modalities, are defined in this review as herbal Chinese medicine products derived from plants or parts of plants used for the treatment of HIV/AIDS.

The objective of this paper is to assess the beneficial and harmful effects of TCHM on patients with HIV infection and AIDS compared with no intervention, placebo, or antiretroviral drug.

\section{Methods}

2.1. Inclusion Criteria. Randomised controlled trials (RCTs) of TCHM in people with HIV infection, HIV-related disease, or AIDS are included irrespective of publication status or language. Observational studies and case series were excluded. TCHM is defined in this paper as herbal Chinese medicine products derived from plants or parts of plants used for the treatment of HIV/AIDS. Controlled intervention can be no treatment, placebo, or antiretrovirals (monotherapy and combination therapies, including HAART).
2.2. Search Strategy for the Identification of Studies. The following electronic databases were searched (between January 1982 and December 2011):

(i) Cochrane HIV/AIDS Group Trials Register, CENTRAL database, the Cochrane Complementary Medicine Field;

(ii) MEDLINE, EMBASE, LILACS, Science Citation Index (SCI), China Network Knowledge Infrastructure (CNKI), and the Chinese Biomedical CD-ROM Database, Traditional Chinese Medical Literature Analysis and Retrieval System (TCMLARS).

The search terms included HIV, acquired-immunodeficiency-syndrome (AIDS), Chinese-medicine, medicineChinese-traditional, medicine-Chinese-herb, herbs, Chinese-herbs.

Chinese Journal of Infectious Diseases, Chinese Journal of Dermatovenereology, Journal for China AIDS/STD Prevention and Control, Chinese Journal of Integrated Traditional and Western Medicine, Research of Traditional Chinese Medicine, and Journal of Traditional Chinese Medicine were handsearched from the first publication date onwards to December 2011. Conference proceedings in Chinese were also handsearched.

Manufacturers of herbal preparations and experts in relevant fields were contacted for potential trials. The bibliographies of identified trials and review articles were checked in order to find randomised trials not identified by the electronic searches or handsearches.

2.3. Data Extraction, Quality, and Risk of Bias Assessment. All articles were read, and data were extracted from the articles based on predefined selection criteria by two independent reviewers. To evaluate the methodological quality of the RCTs, the risk of bias was determined using the Cochrane classification for eight criteria: random sequence generation, allocation concealment, patient blinding, assessor blinding, reporting of dropout or withdrawal, intention-to-treat analysis, selective outcome reporting, and other potential biases [24].

\section{Results}

3.1. Study Description. We screened 257 relevant articles, and 224 were excluded, leaving us with 33 full-text eligible articles. Of these, 22 more were excluded. The remaining 11 RCTs met our inclusion criteria (Figure 1).

Key data from these studies are summarized in Tables 1 and 2 [13-23]. Eleven different kinds of Chinese medicines in a total of 998 patients with HIV infection or AIDS were tested. A placebo procedure was employed in all 11 trials. All of the included trials adopted a two-arm parallel group design [13-23].

3.2. Risk of Bias. The risk of bias in the studies was variable. Nine RCTs had an adequate method for random sequence generation $[13,15-18,20-23]$, whereas the remaining 2 RCTs did not describe $[14,19]$. Allocation concealments were 
TABLE 1: Summary of randomized clinical studies of TCM for treating HIV infections and AIDS.

\begin{tabular}{|c|c|c|c|c|c|c|}
\hline $\begin{array}{l}\text { Study } \\
\text { (country) }\end{array}$ & Design & Participants $(n)$ & Treatment & Control & $\begin{array}{l}\text { Outcome } \\
\text { measures }\end{array}$ & Main findings \\
\hline $\begin{array}{l}\text { Burack et al. } 1996 \\
\text { (US) [13] }\end{array}$ & $\begin{array}{l}\text { Parallel, two } \\
\text { arms, } \\
\text { Double-blind } \\
\text { trial }\end{array}$ & $\begin{array}{l}\text { Symptomatic } \\
\text { patients infected } \\
\text { with HIV with } \\
\text { decreased CD4 } \\
\text { cells (30) }\end{array}$ & $\begin{array}{l}\text { Chinese herbal } \\
\text { preparation } \\
\text { (IGM-1) for } 12 \\
\text { weeks }\end{array}$ & Placebo & $\begin{array}{l}\text { Symptoms, CD4 } \\
\text { cell counts, qulity } \\
\text { of life, adverse } \\
\text { effects }\end{array}$ & $\begin{array}{l}\text { Overall life } \\
\text { satisfaction } \\
\text { improved in patients } \\
\text { treated with herbs, } \\
\text { no difference in CD4 } \\
\text { count and symptom } \\
\text { severity }\end{array}$ \\
\hline $\begin{array}{l}\text { Sangkitporn et al. } \\
2005 \text { (Thailand) } \\
{[14]}\end{array}$ & $\begin{array}{l}\text { Muticentre, } \\
\text { double-blind, } \\
\text { placebo- } \\
\text { controlled } \\
\text { trial }\end{array}$ & $\begin{array}{l}\text { Adults with } \\
\text { HIV-1 infection } \\
(60)\end{array}$ & $\begin{array}{l}\text { Chinese herbal } \\
\text { compound }(\mathrm{SH}) \\
\text { plus ZDV and } \\
\text { ddC for } 24 \text { weeks }\end{array}$ & $\begin{array}{l}\text { Placebo plus ZDV } \\
\text { and ddc for } 24 \\
\text { weeks }\end{array}$ & $\begin{array}{l}\text { HIV RNA, CD4 } \\
\text { counts, adverse } \\
\text { effects }\end{array}$ & $\begin{array}{l}\text { Significant decrease } \\
\text { in HIV RNA levels } \\
\text { in SH group than } \\
\text { placebo without } \\
\text { serious adverse } \\
\text { events }\end{array}$ \\
\hline $\begin{array}{l}\text { Shi and Peng } \\
2003 \\
\text { (China) }[15]\end{array}$ & $\begin{array}{l}\text { Parallel, two } \\
\text { arms, } \\
\text { Double-blind } \\
\text { trial }\end{array}$ & $\begin{array}{l}\text { Adult patients } \\
\text { infected with HIV } \\
\text { and AIDS (36) }\end{array}$ & $\begin{array}{l}\text { Qiankunning } \\
\text { (extracts from } 14 \\
\text { herbs) for } 7 \\
\text { months }\end{array}$ & Placebo & $\begin{array}{l}\text { CD4 cell counts, } \\
\text { viral loads, } \\
\text { adverse effects }\end{array}$ & $\begin{array}{l}\text { Significant decrease } \\
\text { in HIV RNA levels } \\
\text { in herb group than } \\
\text { placebo. Use of } \\
\text { herbs was related to } \\
\text { gastroenterological } \\
\text { adverse effects. }\end{array}$ \\
\hline $\begin{array}{l}\text { Wang et al. } 2006 \\
\text { (China) }[16]\end{array}$ & $\begin{array}{l}\text { Parallel, } \\
\text { double-blind, } \\
\text { placebo- } \\
\text { controlled } \\
\text { trial }\end{array}$ & $\begin{array}{l}\text { Patients infected } \\
\text { with HIV and } \\
\text { AIDS (72) }\end{array}$ & $\begin{array}{l}\text { Chinese herbal } \\
\text { preparation } \mathrm{ZY}-4 \\
\text { for } 6 \text { months }\end{array}$ & Placebo & $\begin{array}{l}\text { CD4 cell counts, } \\
\text { viral loads, } \\
\text { symptom, body } \\
\text { weight, adverse } \\
\text { effects }\end{array}$ & $\begin{array}{l}\text { Significant increase } \\
\text { of CD4 counts in } \\
\text { ZY-4, but not } \\
\text { significant difference } \\
\text { on symptoms, } \\
\text { weight or viral load } \\
\text { between groups }\end{array}$ \\
\hline $\begin{array}{l}\text { Weber et al. } 1999 \\
\text { (Switzerland) } \\
{[17]}\end{array}$ & $\begin{array}{l}\text { Parallel, two } \\
\text { arms, } \\
\text { Double-blind } \\
\text { trial }\end{array}$ & $\begin{array}{l}\text { Adults infected } \\
\text { with HIV with } \\
\text { decreased CD4 } \\
\text { cells (68) }\end{array}$ & $\begin{array}{l}\text { Chinese herbs ( } 35 \\
\text { herbs) for } 6 \\
\text { months }\end{array}$ & Placebo & $\begin{array}{l}\text { AIDS event, CD4 } \\
\text { cell counts, viral } \\
\text { load, quality of } \\
\text { life, adverse } \\
\text { effects }\end{array}$ & $\begin{array}{l}\text { No positive findings } \\
\text { for the outcome and } \\
\text { herbs associated } \\
\text { with adverse effects }\end{array}$ \\
\hline $\begin{array}{l}\text { Wang et al. } 2008 \\
\text { (China) }[18]\end{array}$ & $\begin{array}{l}\text { Parallel, two } \\
\text { arms, placebo- } \\
\text { controlled } \\
\text { Double-blind } \\
\text { trial }\end{array}$ & $\begin{array}{l}\text { adults infected } \\
\text { with HIV, } \\
\text { received HAART } \\
\text { therapy for } 0.5-1 \\
\text { year }(100)\end{array}$ & $\begin{array}{l}\text { Chinese herbal } \\
\text { preparation } \\
\text { Aining Granule } \\
\text { (AG) plus d4T, } \\
\text { ddI and NVP for } \\
11 \text { months }\end{array}$ & $\begin{array}{l}\text { placebo plus d4T, } \\
\text { ddI and NVP for } \\
11 \text { months }\end{array}$ & $\begin{array}{l}\text { Symptoms, CD4 } \\
\text { cell counts, viral } \\
\text { loads, CD8, IL-2, } \\
\text { IL- } 4, \text { IFN- } \gamma \text {, } \\
\text { adverse effects }\end{array}$ & $\begin{array}{l}\text { Significant decrease } \\
\text { of CD4 counts in } \\
\text { placebo group, } \\
\text { improvement of } \\
\text { symptoms of } \\
\text { anepithymia, } \\
\text { diarrhea and nausea, } \\
\text { but not significant } \\
\text { difference on viral } \\
\text { load, CD8, IL-2,4 } \\
\text { between groups }\end{array}$ \\
\hline $\begin{array}{l}\text { Jiang et al. } 2009 \\
\text { (China) [19] }\end{array}$ & $\begin{array}{l}\text { Parallel, two } \\
\text { arms, } \\
\text { controlled } \\
\text { open label trial }\end{array}$ & $\begin{array}{l}\text { Patients who are } \\
\text { HIV infection } \\
\text { and AIDS with } \\
\text { oral candidiasis } \\
\text { symptoms }(80)\end{array}$ & $\begin{array}{l}\text { Chinese herbal } \\
\text { preparation } \\
\text { XiaoMi Granule } \\
\text { (XMG) plus } \\
\text { Nystatin for } \\
\text { external use for } 2 \\
\text { weeks }\end{array}$ & $\begin{array}{l}\text { Nystatin for } 2 \\
\text { weeks }\end{array}$ & $\begin{array}{l}\text { Symptoms of oral } \\
\text { candidiasis, } \\
\text { adverse effects }\end{array}$ & $\begin{array}{l}\text { Significant } \\
\text { improvement of } \\
\text { symptoms of oral } \\
\text { candidiasis in herb } \\
\text { group, no adverse } \\
\text { event was found }\end{array}$ \\
\hline $\begin{array}{l}\text { Jiang et al. } 2011 \\
\text { (China) [20] }\end{array}$ & $\begin{array}{l}\text { Parallel, } \\
\text { double-blind, } \\
\text { double dummy } \\
\text { trial }\end{array}$ & $\begin{array}{l}\text { Patients who are } \\
\text { HIV infection } \\
\text { and AIDS with } \\
\text { leukopenia } \\
\text { symptoms (116) }\end{array}$ & $\begin{array}{l}\text { Chinese herbal } \\
\text { preparation } \\
\text { Jingyuankang } \\
\text { Capsule (JC) plus } \\
\text { AZT, ddI, NVP } \\
\text { and analogue } \\
\text { Leucogen Tablets } \\
\text { for } 6 \text { months }\end{array}$ & $\begin{array}{l}\text { Leucogen Tablets } \\
\text { plus AZT, ddI, } \\
\text { NVP and } \\
\text { analogue JC }\end{array}$ & $\begin{array}{l}\text { Peripheral } \\
\text { leukocytes, } \\
\text { adverse effects }\end{array}$ & $\begin{array}{l}\text { Significant increase } \\
\text { of peripheral } \\
\text { leukocytes without } \\
\text { serious adverse } \\
\text { events }\end{array}$ \\
\hline
\end{tabular}


Table 1: Continued.

\begin{tabular}{|c|c|c|c|c|c|c|}
\hline $\begin{array}{l}\text { Study } \\
\text { (country) }\end{array}$ & Design & Participants $(n)$ & Treatment & Control & $\begin{array}{l}\text { Outcome } \\
\text { measures }\end{array}$ & Main findings \\
\hline $\begin{array}{l}\text { Xu et al. } 2011 \\
\text { (China) }[21]\end{array}$ & $\begin{array}{l}\text { Parallel, } \\
\text { double-blind, } \\
\text { double dummy } \\
\text { trial }\end{array}$ & $\begin{array}{l}\text { Patients with } \\
\text { AIDS and } \\
\text { diarrhea (158) }\end{array}$ & $\begin{array}{l}\text { Chinese herbal } \\
\text { preparation } \\
\text { Xielikang Capsule } \\
\text { (XC) plus } \\
\text { analogue } \\
\text { loperamide for } 14 \\
\text { days }\end{array}$ & $\begin{array}{l}\text { Loperamide plus } \\
\text { analogue XC for } \\
14 \text { days }\end{array}$ & $\begin{array}{l}\text { Symptoms of } \\
\text { diarrhea, adverse } \\
\text { effects }\end{array}$ & $\begin{array}{l}\text { Improvement of } \\
\text { symptom of } \\
\text { diarrhea in herb } \\
\text { group }\end{array}$ \\
\hline $\begin{array}{l}\text { Xie et al. } 2008 \\
\text { (China) [22] }\end{array}$ & $\begin{array}{l}\text { Parallel, two } \\
\text { arms, placebo- } \\
\text { controlled } \\
\text { Single-blind trial }\end{array}$ & $\begin{array}{l}\text { Patients infected } \\
\text { with HIV and } \\
\text { AIDS with CD4 } \\
250-600 \\
\text { cells/mm } \text { m }^{3} \\
\text { without HAART } \\
\text { therapy (102) }\end{array}$ & $\begin{array}{l}\text { Aikang Capsule } \\
\text { (AC) for } 6 \\
\text { months }\end{array}$ & $\begin{array}{l}\text { Placebo for } 6 \\
\text { months }\end{array}$ & CD4 cell counts & $\begin{array}{l}\text { No significant } \\
\text { difference between } \\
\text { groups. }\end{array}$ \\
\hline $\begin{array}{l}\text { Shao } 2008 \\
\text { (China) }[23]\end{array}$ & $\begin{array}{l}\text { Parallel, two } \\
\text { arms, placebo- } \\
\text { controlled } \\
\text { Double-blind } \\
\text { trial }\end{array}$ & $\begin{array}{l}\text { Patients infected } \\
\text { with HIV and } \\
\text { AIDS } \\
\text { Without HAART } \\
\text { therapy (176) }\end{array}$ & $\begin{array}{l}\text { Tangcao Tablets } \\
\text { (TT) for } 6 \\
\text { months }\end{array}$ & $\begin{array}{l}\text { Placebo for } 6 \\
\text { months }\end{array}$ & $\begin{array}{l}\text { CD4 cell counts, } \\
\text { viral loads, } \\
\text { symptom, body } \\
\text { weight, adverse } \\
\text { effects }\end{array}$ & $\begin{array}{l}\text { Significant increase } \\
\text { of CD4 counts, } \\
\text { CD4/CD8 and } \\
\text { weight in herb } \\
\text { group, significant } \\
\text { decrease of viral } \\
\text { load in placebo } \\
\text { group, improvement } \\
\text { of symptoms in herb } \\
\text { group. }\end{array}$ \\
\hline
\end{tabular}

adequately performed in 10 RCTs [13-19, 21-23]. Patient and assessor blinding was reported in 10 of the RCTs [1319, 21-23], whereas one RCT employed patient blinding only [22]. Reasons for dropouts and withdrawals were fully described in 11 trials [13-23]. Only four studies employed the ITT method $[13,17,21,23]$, but the remaining studies had missing outcome data balanced in numbers across intervention groups, with similar reasons for missing data across groups, except one study [14]. All of the included RCTs had a low risk of bias in selective outcome reporting. The sample size ranged from 30-176 patients. Overall, the methodological quality of the trials was adequate.

3.3. Efficacy and Safety. Due to the limited number of trials identified and the variation of participants and herbal preparations, meta-analysis and the prespecified subgroup or sensitivity analyses were not performed.

3.3.1. IGM-1. A randomized trial tested a Chinese herbal formulation (IGM-1) composed of 31 Chinese herbs (Table 1) in 30 HIV-infected adults with symptoms and decreased CD4+ cell count $\left(200-499 / \mathrm{mm}^{3}\right)$ for treatment of HIV-related symptoms for duration of 12 weeks [13]. The study found a significant better effect in improvement of health-related QoL in terms of life satisfaction and symptoms than placebo. The number of symptoms was reduced in patients receiving herbs, but not in those receiving placebo. There were no statistically significant differences in overall health perception, symptom severity, CD4 counts, anxiety, or depression between groups. No adverse events were reported among participants. However, the above results need to be accounted for with care due to the small sample in the trial.

3.3.2. "35-Herb". Interestingly, three years after the above trial was published, the same investigator who prescribed IGM-1 prescribed another Chinese herbal formulation that was tested in a trial in Switzerland [17]. The formulation was composed of 35 Chinese herbs containing most of the herbs listed in IGM-1 (Table 1). A trial tested the Chinese herbal formulation in $68 \mathrm{HIV}$-infected adults with decreased CD4+ cell count (less than $500 / \mathrm{mm}^{3}$ ) for a treatment period of six months [17]. The participants were randomized to receive "35-herb" $(n=34)$ or placebo $(n=34)$. Over $70 \%$ of the patients had received previous antiretroviral therapy, the two groups were comparable regarding sociodemographic characteristics, previous antiretroviral use, viral load, CD4+ cell counts, and other clinical laboratory tests at entry. A total of $53(78 \%)$ patients completed treatment for 6 months, including 24 in the herb group and 29 in the placebo group. Analyses were based on complete data and on intention-totreat principle in the trial report. After six months, there was no significant difference in CD4+ cell counts, viral load, new AIDS-defining events, number of reported symptoms, psychosocial measurements or QoL between two groups.

The total number of reported adverse events was 46 in the herb group and 20 in the placebo group, and included diarrhea, increased number of daily bowel movements, abdominal pain, constipation, flatulence, and nausea. Hematological or serum chemistry laboratory values showed no 


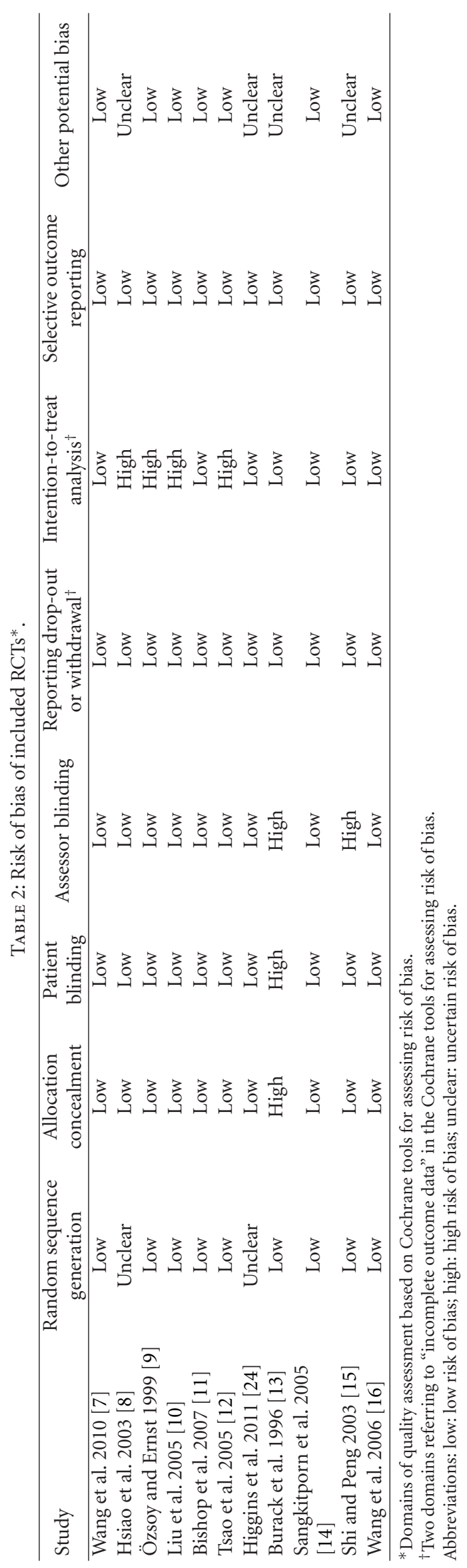




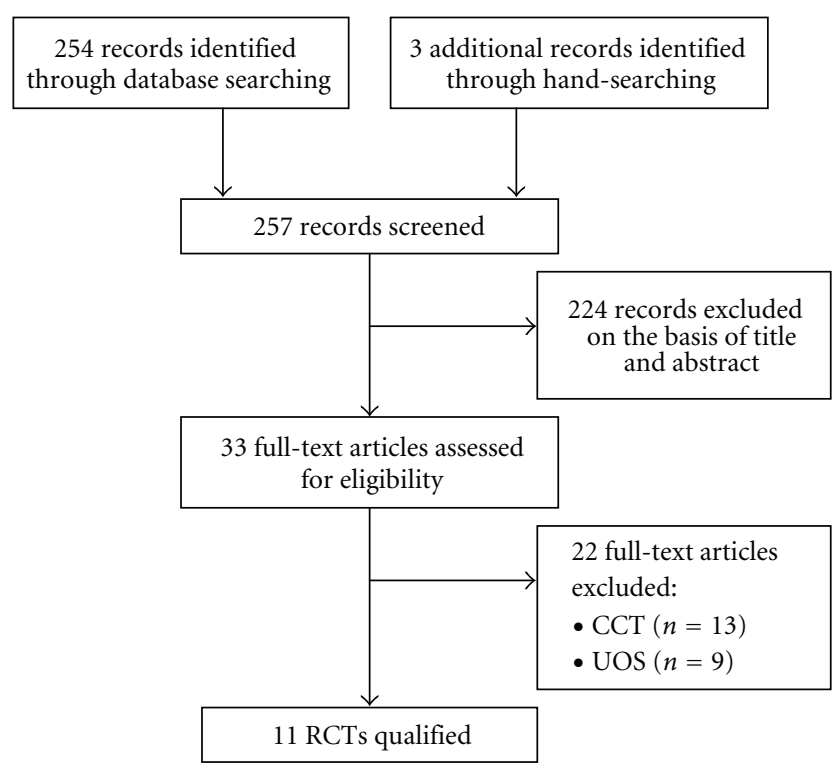

CCT: controlled clinical trial; UOS: uncontrolled observational study;

Figure 1: Flow diagram of literature search.

evidence of toxicity from the study herbs. Two patients in the herb group died during the study period and causes of death were believed to be due to severe immunodeficiency and preenrolment history of severe opportunistic complications, but not related to the study drugs.

3.3.3. Compound SH. Compound SH containing five herbs (Table 1) were combined with zidovudine and zalcitabine in the treatment of $60 \mathrm{HIV}$-infected Thai patients in a randomized trial [14]. The herbal formula was made from more than 1000 chinese herbs from 120 plant families by Kunming Institute of Botany of the Chinese Academy of Science. The trial found that adding $\mathrm{SH}$ herbs to the two nucleoside reverse transcriptase inhibitors has a greater antiviral activity than antiretrovirals only. However, the data analyses were based on participants, who had completed the trial, 22 subjects who lost followup or withdrawal due to adverse events were excluded, and the above benefits need to be accounted for with care.

3.3.4. Qiankunning. Qiankunning (Table 1) is a Chinese herb preparation extracted from 14 herbs. A randomized, double blind placebo controlled trial was conducted in 2003 in China [15], 36 adults with HIV infection or AIDS were randomized to receive Qiankunning $(n=18)$ or placebo $(n=18)$. Patients were comparable regarding age, body weight, average duration of drug abuse, and pre trial HIV RNA levels. No intention to treat analyses were applied, the data analyses were based on participants who had completed the trial. Significant decrease in HIV RNA levels was found in herb group than placebo after the end of treatment for 7 months. In this trial, the use of herbs was related to stomach discomfort and diarrhea. No adverse effects were reported from the placebo group. There were no serious adverse events observed.

3.3.5. Zhongyan-4. Chinese herbal medicine zhongyan-4 (ZY-4) (Table 1) is prepared by the Chinese Academy of Chinese Medical Sciences in Beijing, China. A randomized, double blind placebo controlled trial enrolled 72 patients with HIV infection or AIDS (36 with herbs and 36 with placebo) [16]. CD4+ cell counts in the ZY-4 group were increased by $7.7 \pm 150.96$ cells $/ \mathrm{mm}^{3}$, while in the placebo group the CD4+ cell counts were decreased by $27.33 \pm 85.28$ cells $/ \mathrm{mm}^{3}$ after treatment for 6 months $(P>0.05)$. A total of 15 out of 30 patients ( 6 dropped out) in the ZY- 4 group had their CD4 count increased compared with 8 out of 33 patients ( 3 dropped out) in the placebo group $(P<0.05)$. The study concludes that ZY-4 is effective in enhancing immunity function based on CD4+ cell counts. However, this study showed no significant difference in body weight or viral load after treatment between ZY-4 and placebo.

3.3.6. Aining Granule. The Chinese herbal medicine Aining Granule (AG) (Table 1) was tested in 100 patients compared with placebo in a double blind trial. Participants were randomized into two groups [18], AG group $(n=50)$ received AG+HAART (d4T+ddI+NVP) and Placebo group $(n=50)$ received placebo + HAART $(\mathrm{d} 4 \mathrm{~T}+\mathrm{ddI}+\mathrm{NVP})$. $\mathrm{CD} 4+$ cell counts in the AG group were decreased by $87.65 \pm$ 107.98 cells $/ \mathrm{mm}^{3}$, while in the placebo group the CD4+ cell counts were decreased by $156.51 \pm 157.04$ cells $/ \mathrm{mm}^{3}$ after treatment for 11 months $(P<0.05)$. Significant improvement of symptoms such as fatigue, anorexia, nausea, diarrhea, skin rash was found in AG group. The results showed that patients receiving Chinese herb AG had a lower risk for the decrease of CD4+ cell counts. However, this study showed no significant difference between two groups in viral load after treatment.

3.3.7. Xiaomi Granule. A randomized two arms positivedrug controlled open label trial was conducted in 2009 in china, in which 80 AIDS participants with oral candidiasis were included in the Xiaomi Granule (Table 1) plus Nystatin group $(n=40)$ and Nystatin group $(n=40)$ [19]. After treatment for 2 weeks, significant improvement of symptoms of oral candidiasis was found in herb group. No adverse event was found. Xiaomi Granule is a Chinese herb preparation developed from a prescription in classic Chinese medicine ancient book "jin kui yao lve". There is no description of $\mathrm{CD} 4+$ cell counts and viral load in the paper available.

3.3.8. Jingyuankang Capsule. In a double-blind, doubleanalogue trial, 116 participants with HIV infection and peripheral leucopenia were randomized to receive Jingyuankang Capsule (JC) (Table 1) plus AZT, ddI, NVP, and analogue Leucogen Tablets $(n=58)$ or Leucogen Tablets plus AZT, ddI, NVP and analogue JC $(n=58)$ for 6 months [20]. The application of JC showed significant increase of peripheral leukocytes in herb group. CD4+ cell count outcome was not reported. There were no significant 
differences between the groups regarding adverse effect in the trial report.

3.3.9. Xielikang Capsule. A randomized, double-blind, double dummy and controlled clinical trial was conducted between 2009 and 2011 in china, in which 158 AIDS-related chronic diarrhea patients were randomized into Xielikang Capsule (XC) (Table 1) plus loperamide analogue group $(n=106)$ and loperamide capsule plus XC analogue group $(n=52)$ [21]. The primary efficacy parameters were stool weight, abnormal stool frequency and score of diarrhea questionnaire. All the patients have no recognized enteritis or intestinal canal identified from enteroscope or diarrhea resulted by protease inhibitors (PI) drugs. According to an analysis of the treatment effect over 7 and 14 days based on daily measurements, Patients who were treated with $\mathrm{XC}$ experienced a statistically significant reduction in stool weight $(P=0.0029$ in 7 days and $P=0.0023$ in 14 days $)$ and in diarrhea questionnaire score $(P<0.01$ in 14 days $)$. There were no significant differences between groups with respect to stool frequency. No serious adverse events were reported. There was no major difference between XC and placebo in the occurrence of adverse events or in laboratory abnormalities.

3.3.10. Aikang Capsule. A randomized placebo controlled trial enrolled 102 patients infected with HIV and AIDS with CD4+ cell counts between 250 and 600 cells $/ \mathrm{mm}^{3}$ who were treated with Aikang Capsule (Table 1) or placebo for 6 months [22]. There was no significant difference in CD4+ cell counts between two groups.

3.3.11. Tangcao Tablets. In a China phase III clinical muticenter trial conducted between 2002 and 2003, 176 patients with CD $4+$ cell counts $>200$ cells $/ \mathrm{mm}^{3}$ were randomized to receive a 6- month course of treatment with Chinese herbal medicine Tangcao Tablets (Table 1$)(n=88)$ or placebo $(n=88)$ [23]. Patients receiving antiretroviral drugs were excluded. Both intention to treat analysis and per-protocol analysis showed significant increase in CD4 counts, CD4/CD8 ratio and weight in herb group, significant increase of viral load in placebo group, improvement of symptoms in herb group.

The total number of reported adverse events was 21 in the herb group and 27 in the placebo group, and included diarrhea, cold, abdominal pain, flatulence, and nausea. Hematological or serum chemistry laboratory values showed no evidence of toxicity from the study herbs. Two patients in the placebo group died during the study period and causes of death were believed to be due to severe immunodeficiency and pre-enrolment history of severe opportunistic complications, but not related to the placebo.

\section{Discussion}

Due to the limited number of RCTs for included trials, the small sample size of each study, we are not able to draw firm conclusions concerning TCHM therapy in treating patients with HIV infection and AIDS. Compared with placebo, TCHM demonstrated positive effects in improving QoL and symptoms, increasing CD4+ cell counts; however, the quality of studies need to be concerned. Our paper aimed to update and complete the evidence of TCHM treatments for patients with HIV infections and AIDS. Compared to a previous paper [10], we identified 6 new RCTs and successfully updated the evidence. The results of our paper are similar to that of the previous paper [10], which also expressed concern regarding the beneficial effects need to be considered with caution because the number of patients in these trials was small and the size of the effects quite moderate.

Some studies support the Chinese herb and antiretroviral drug combination therapy $[14,18]$. A promising additional antiviral benefit was found from Compound $\mathrm{SH}$ combined with antiretroviral agents; however, high drop out rate should be taken into consideration. Wang Jian et al. provide evidence in improving symptoms and a lower risk for the decrease of CD4+ cell counts for patients with combined therapy using Chinese herb Aining granule. Studies of diarrhea and oral candidiasis, which are challenging symptoms of AIDS, were demonstrated to have positive effects [19, 21]. Study of peripheral leukocytes, which are a side effect of antiretroviral drugs, suggested that an integrated treatment approach may be of benefit [20]. The use of Chinese herbs is associated with non-serious adverse effects in our included trials. However, potential risk of interaction between herbs and antiretroviral drugs need more explorations.

The methodological limitations of the studies reported in this systematic literature review included small sample sizes, non-reporting of followup, insufficient details on sampling, high drop-out rates, lack of intention to treat analysis and lack of blinding. The reporting of studies was also very limited for included papers, with items most commonly missing from the CONSORT checklist including: 1a (identification as RCT in title); 16 (numbers of participants included in each analysis); 6b (changes to trial outcomes); 8, 9, and 10 (details of randomisation procedure); $14 \mathrm{~b}$ (why the trial was ended); and 23 and 24 (registration number and full protocol access) [25]. STRICTA guidelines should be adopted [26].

Our paper has a number of important limitations. Although strong efforts were made to retrieve all RCTs on the subject, we cannot be absolutely certain that we succeeded. Moreover, selective publishing and reporting are other major causes for bias, which must be considered. It is conceivable that several negative RCTs remain unpublished. Together, these factors limit the conclusiveness of this systematic review considerably.

In conclusion, the results of our systematic review provide limited evidence for the effectiveness of TCHM in treating patients with HIV infection and AIDS. Thus, drawing firm conclusions concerning the effectiveness of CAM therapies remains difficult. Further large and rigorous RCTs are warranted.

\section{Conflict of Interests}

There is no conflict of interests among the authors. 


\section{Acknowledgment}

The work was supported by National Major Science and Technology Specific Project of China (2013zx10005001).

\section{References}

[1] N. He and R. Detels, "The HIV epidemic in China: history, response, and challenge," Cell Research, vol. 15, no. 11-12, pp. 825-832, 2005.

[2] F. J. Zhang, Z. H. Dou, L. Yu et al., "The effect of highly active antiretroviral therapy on mortality among HIV-infected former plasma donors in China," Clinical Infectious Diseases, vol. 47, no. 6, pp. 825-833, 2008.

[3] F. J. Zhang, Z. H. Dou, Y. Ma et al., "Effect of earlier initiation of antiretroviral treatment and increased treatment coverage on HIV-related mortality in China: a national observational cohort study," The Lancet Infectious Diseases, vol. 11, no. 7, pp. 516-524, 2011.

[4] Y. Cui, A. Liau, and Z. Y. Wu, "An overview of the history of epidemic of and response to HIV/AIDS in China: achievements and challenges," Chinese Medical Journal, vol. 122, no. 19, pp. 2251-2257, 2009.

[5] L. Alain and S. Mario, "The search for a cure for persistent HIV reservoirs,” AIDS Review, vol. 13, no. 2, pp. 63-66, 2011.

[6] J. Liu, "The use of herbal medicines in early drug development for the treatment of HIV infections and AIDS," Expert Opinion on Investigational Drugs, vol. 16, no. 9, pp. 1355-1364, 2007.

[7] J. Wang, W. Zou, Y. Liu et al., "Assessing the effect of traditional Chinese medicine on CD4 cell count of 807 HIV/AIDS patients," Journal of Biomedical Science and Engineering, vol. 3, no. 8, pp. 828-831, 2010.

[8] A. F. Hsiao, M. D. Wong, D. E. Kanouse et al., "Complementary and alternative medicine use and substitution for conventional therapy by HIV-infected patients," Journal of Acquired Immune Deficiency Syndromes, vol. 33, no. 2, pp. 157165, 2003.

[9] M. Özsoy and E. Ernst, "How effective are complementary therapies for HIV and AIDS? - a systematic review," International Journal of STD and AIDS, vol. 10, no. 10, pp. 629-635, 1999.

[10] J. P. Liu, E. Manheimer, and M. Yang, "Herbal medicines for treating HIV infection and AIDS," Cochrane Database of Systematic Reviews, no. 3, Article ID CD003937, 2005.

[11] F. L. Bishop, L. Yardley, and G. T. Lewith, "A systematic review of beliefs involved in the use of complementary and alternative medicine," Journal of Health Psychology, vol. 12, no. 6, pp. 851$867,2007$.

[12] J. C. I. Tsao, A. Dobalian, C. D. Myers, and L. K. Zeltzer, "Pain and use of complementary and alternative medicine in a national sample of persons living with HIV," Journal of Pain and Symptom Management, vol. 30, no. 5, pp. 418-432, 2005.

[13] J. H. Burack, M. R. Cohen, J. A. Hahn, and D. I. Abrams, "Pilot randomized controlled trial of Chinese herbal treatment for HIV-associated symptoms," Journal of Acquired Immune Deficiency Syndromes and Human Retrovirology, vol. 12, no. 4, pp. 386-393, 1996.

[14] S. Sangkitporn, L. Shide, V. Klinbuayaem et al., "Efficacy and safety of zidovudine and zalcitabine combined with a combination of herbs in the treatment of HIV-infected Thai patients," Southeast Asian Journal of Tropical Medicine and Public Health, vol. 36, no. 3, pp. 704-708, 2005.
[15] D. Shi and Z. L. Peng, "Randomised, double-blind, placebocontrolled clinical study on Qiankunning for HIV/AIDS," China Journal of Chinese Medicine, vol. 21, no. 9, pp. 14721474, 2003.

[16] J. Wang, F. Z. Yang, M. Zhao et al., "Randomized doubleblinded and controlled clinical trial on treatment of HIV/ AIDS by Zhongyan-4," Chinese Journal of Integrative Medicine, vol. 12, no. 1, pp. 6-11, 2006.

[17] R. Weber, L. Christen, M. Loy et al., "Randomized, placebocontrolled trial of Chinese herb therapy for HIV-1-infected individuals," Journal of Acquired Immune Deficiency Syndromes and Human Retrovirology, vol. 22, no. 1, pp. 56-64, 1999.

[18] J. Wang, Y. Liu, W. Zou et al., "Clinical observations on 100 HIV/AIDS cases treated with Chinese herb aining granule plus HAART," Chinese Journal of AIDS \& STD, vol. 14, no. 2, pp. 101-107, 2008.

[19] F. Jiang, S. H. Wei, B. Peng et al., "Effect of Xiaomi granule in treating 40 patients of HIV/AIDS oral candidiasis," Chinese Journal of Integral Medicine, vol. 29, no. 12, pp. 1117-1119, 2009.

[20] S. Q. Jiang, H. X. Sun, Y. M. Xu, Y. L. Jiang, J. W. Pei, and H. L. Wang, "Effects of Jingyuankang capsules on leukocyte level in AIDS patients," Journal of Traditional Chinese Medicine, vol. 31, no. 1, pp. 32-35, 2011.

[21] Z. Xu, X. P. Yang, L. Ni et al., "Clinical study on Xielikang capsule in treatment of AIDS-related chronic diarrhea," Global Traditional Chinese Medcine, vol. 14, no. 3, pp. 197-200, 2011.

[22] S. P. Xie, W. Q. Pan, H. J. Guo et al., "Effect of Aikang capsule on immune function of HIV/AIDS patients," Liao Ning Journal of Traditional Chinese Medicine, vol. 35, no. 2, pp. 165-167, 2008.

[23] B. P. Shao, "Clinical effect and safety report on HIV/AIDS patients with Tangcao tablets," in Proceedings of the 6th Conference on HIV/AIDS Treatment with TCM, China Association of Traditional Chinese Medicine, Anhui, China, December 2008.

[24] J. P. T. Higgins, D. G. Altman, and J. A. C. Sterne, "Assessing risk of bias in included studies," in Cochrane Handbook for Systematic Reviews of Interventions Version 510, J. P. T. Higgins and S. Green, Eds., chapter 8, The Cochrane Collaboration, 2011, http://handbook.cochrane.org.

[25] K. F. Schulz, D. G. Altman, D. Moher, and CONSORT Group, "CONSORT 2010 statement: updated guidelines for reporting parallel group randomised trials," BMC Medicine, vol. 8, article 18, 2010.

[26] H. MacPherson, D. G. Altman, R. Hammerschlag et al., "Revised standards for reporting interventions in clinical trials of acupuncture (STRICTA): extending the CONSORT statement," Journal of Evidence-Based Medicine, vol. 3, no. 3, pp. 140-155, 2010. 


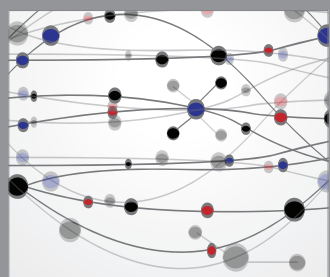

The Scientific World Journal
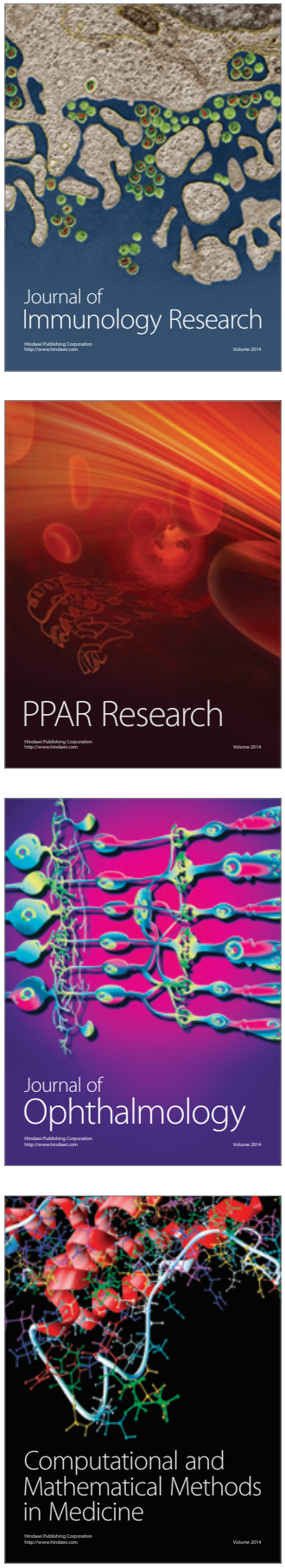

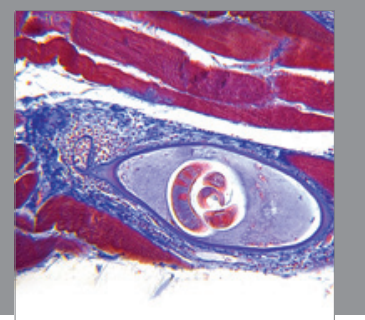

Gastroenterology

Research and Practice
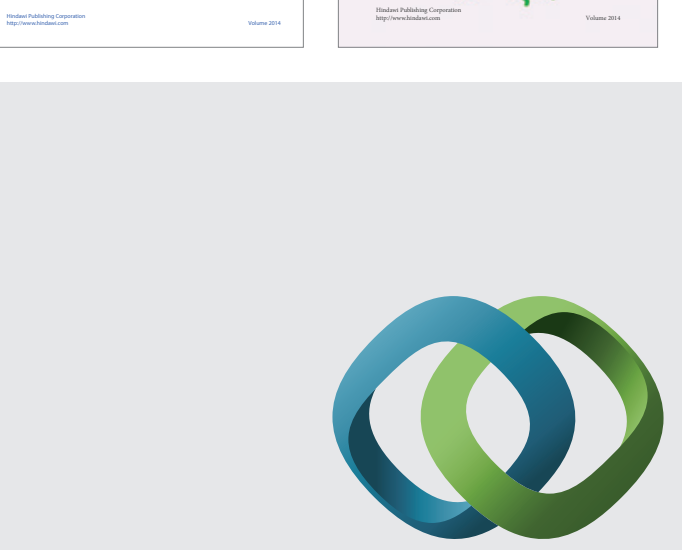

\section{Hindawi}

Submit your manuscripts at

http://www.hindawi.com
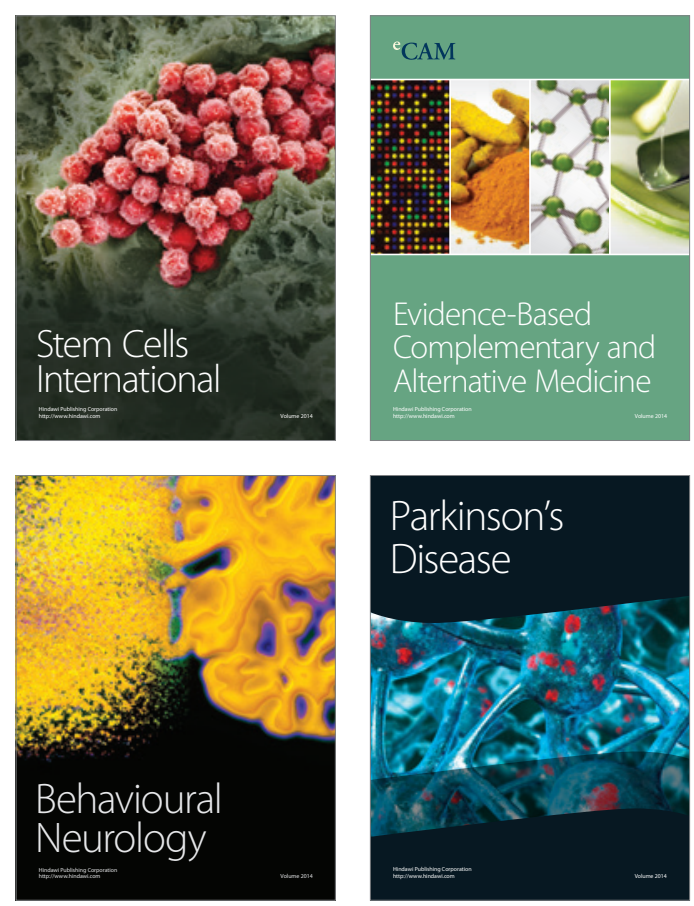

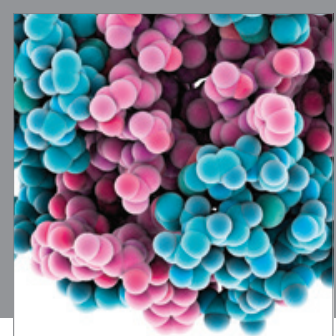

Journal of
Diabetes Research

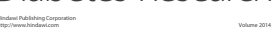

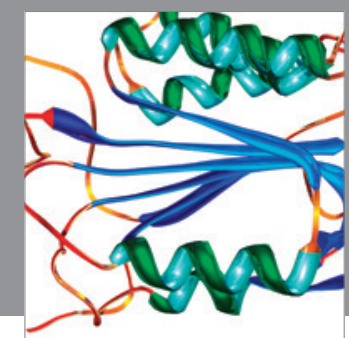

Disease Markers
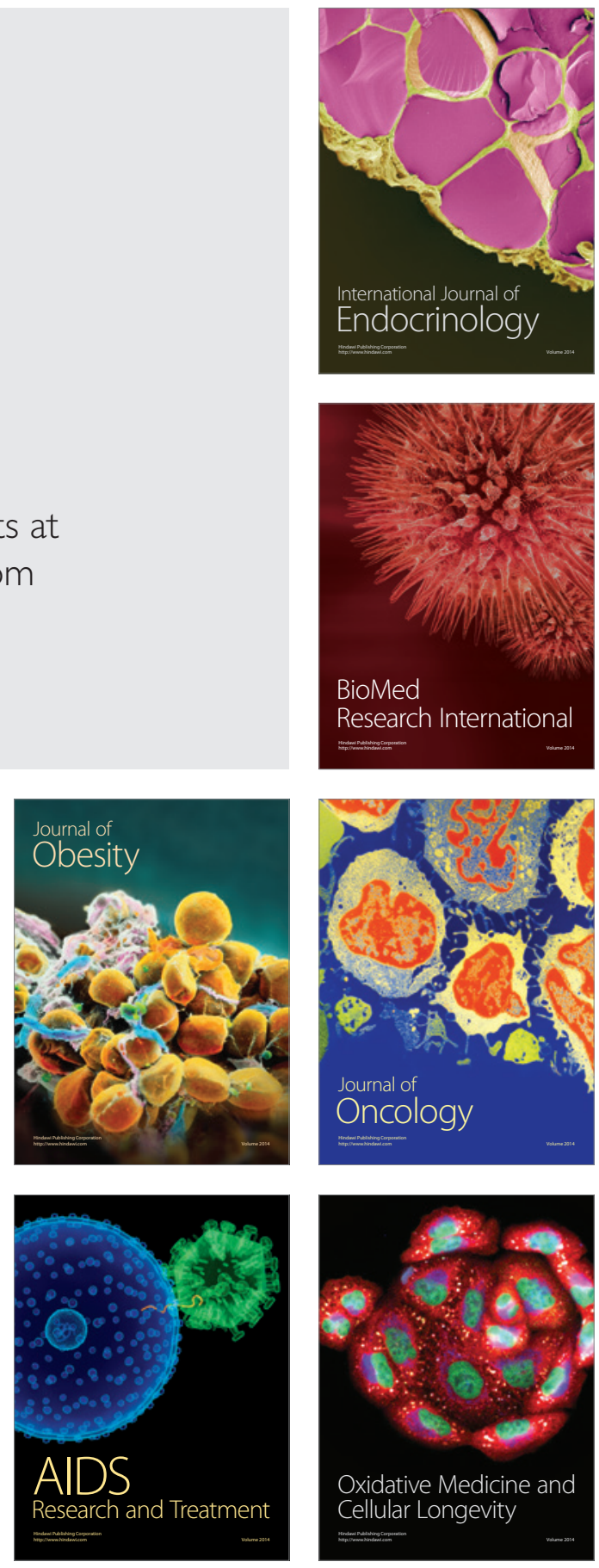